\title{
Relationship between religiosity and psychological distress among college students in Indonesia
}

\author{
Intan Kusumadewi ${ }^{1}$ and Sugiarti Musabiq ${ }^{2}$ \\ ${ }^{1,2}$ Psychology Faculty, University of Indonesia, Depok, Indonesia \\ *E-mail: Email: kira.intan@gmail.com
}

\begin{abstract}
College students are prone to psychological distress due to their own characteristics. Numerous experiences happened around these populations, such as academic pressure, love life problems, family issues and so on. College students are emerging adults that most likely doing things to explore many aspects in their life. Religiosity is one of many aspects from emerging adult's life that is being explored while they are still in college. Previous study using college student found that college students show decreasing religious practice. Meanwhile it is known that the more religious a person the lesser his or her psychological distress. The objective of this study is to identify the relationship between religiosity and psychological distress among college students. HSCL-25 and CRS-15 is used to measure psychological distress and religiosity in 1,959 college students from several cities of Indonesia. The finding is that 4 from 5 dimensions of religiosity have a significant relationship with psychological distress.
\end{abstract}

\section{Keywords: college student, emerging adult psychological distress, religiosity}

\section{Introduction}

According to Arnett (2006) 50 years ago people at the age of 22 to 24 at least already have a family and should be responsible to take care their own expense, and therefore they are being adult. Things change overtime, technology development and easier access to higher education for both men and women resulting in delayed marriage. When 50 years ago at the age of 22 people already entering adulthood, now at the age of 22 they are not classified as an adult based on Arnett explanations. Arnett (2006) explain that at the age 18 to 25 people are not adult yet, beside they are in a phase called emerging adult.

Most emerging adults are in their college year. Different student in different college year have their own pressures and problems. Greenberg (2002) explain that not just freshmen but also seniors, both will face problems that have negative effect on them. Acharaya (2009) found that among many population, college student in their 20 s are very susceptible to stress and this will affect their performance. Selye in 1978 explain that stress is the nonspecific response of the body to any demand. There are two kinds of stress, eustress and distress. Distress is the form of stress characterize by lowering performances, unpleasant, and can be harmful. Prolong distress not only caused unpleasant feeling but also mental disorder, depression, and suicide ideation. Mirowsky and Ross (2003) explain that distress is subjective condition that have two main form, depression and anxiety. Mirowsky and Ross (2003) describe forms of depression as feeling sad, demoralizing, hopeless, feeling worthless, suicide ideation, sleeplessness, crying constantly, feeling the need for hard work to do anything, and feeling unable to perform activities. Meanwhile, form of anxiety are feeling tense, unable to rest, worry, irritable, and fear. According to Greenberg (2002) stress can lead to reactions such as irritability, anxiety and depression, frequent urination, diarrhea or constipation, nausea and vomiting, and other illnesses that are sometimes difficult to explain by the medical team. Conditions like this certainly disrupt one's activities.

Study results from Ross (1990), conducted in Illinois with 401 respondents, found that strong belief towards the religion associated with lower level of distress. While people with low or moderate belief levels have higher levels of psychological distress. Liu, Schieman and Jang (2011) also reported that someone who doing more prayer and follow religious activities had less psychological distress. A study conducted in Indonesia by Astri (2009) found that respondents who have low stress levels, have a high level of religiosity. In contrast, some studies 
show that religiosity has no relationship or even influence with the degree of distress. As Research Raza, Yousaf, and Rasheed (2016) in Pakistan do with 100 respondents, found that religiosity is a factor that can predict the person's welfare. In the same study also found that welfare is a negative predictor of psychological distress. However, religiosity does not have a significant relationship to psychological distress. similar result also found by O'Connor, Cobb, and O'Connor (2003) that there was no significant relationship between religiosity and psychological distress in college students.

Stark and Glock (1968) make it clear that so far there are differences in one's perspective on the meaning of religion. Religious can be mean diligently worshiping, know the teachings of religion well, or strongly believe with the ideology of religion. The details of what is meant by religion differ in each religion, so it becomes difficult to find a definition that describes religiosity for the whole religion. Furthermore, they explain that eventhough different definition of religion but, there is a common understanding of how religiosity is manifested. This understanding became the basis of the five major dimensions of religiosity proposed by Stark and Glock (1968). These five dimensions are belief, religious practice, knowledge, experience, and consequences. In its development they made a revision hence the dimension of religious practice became a public religious practice and personal religious practice, then the consequences dimension is eliminated.

In some previous studies the relationship between the dimensions of religiosity and psychological distress has been investigated. As in the research conducted by Jarvis, Kirmayer, Weinfeld, and Lasry (2005) found that the presence in religious activity has a negative relationship to psychological distress. According to their study by following religious activities in the house of worship, allow time to escape the problems faced at home and meet with friends, which in turn can provide social support for the person. The same study Jarvis, Kirmayer, Weinfeld, and Lasry (2005) found that religious activities conducted within the home or in private have no relationship to psychological distress. Ellison and Fan (2008) examine daily religious experiences and their relation to the well-being of the American population. As a result, it was found that everyday religious experiences have a positive relationship with well-being. Another finding from Ellison and Fan's (2008) study is the experience of daily life that should have an antidote to psychological distress. There is no significant relationship between the two.
Studies related to the dimensions of religiosity with psychological distress are more common in the western population and not in Asian populations. Many of those previous studies only focus on one religions that common in their area. Moreover, the tools they used to measure religiosity are only for one religion, and a few of them are just an open question about how someone thinks of their religiosity. In addition, the relationship between religiosity and psychological distress is debatable. In this study, we are interested to see how the religiosity and psychological distress relation in the college student population in Indonesia. Using a newer tool called CRS-15 that have been adapted to use in Indonesi to measure religiosity of 5 different religions.

Sample. Respondents in this study are college students aged 18 to 25 years old and still active in college throughout Indonesia. This study uses data from 1959 respondents. Data collection using convenience sampling method. In the data collection, researchers distributed questionnaires in two forms, offline and online. Number of offline respondents whose data used in this study are 337. Respondents' data used from the online questionnaire are 1,622. Online respondents have the opportunity to win a bag and phone credits, while the offline respondent will get a package of pen and notebook.

Research Design. This research is a correlational research because researchers want to see the relationship between religiosity and psychological distress in college students. This study uses quantitative data collected through the use of measuring instruments for both variables. The data analysis techniques used in this study are partial correlation.

Instrument and Measurement. In this study, psychological distress was measured using the Hopkins Symptom Checklist-25 (HSCL-25) Indonesian version that has been adapted by Turnip and Hauff (2007). In the research Turnip and Hauff (2007) itself found that HSCL-25 has internal consistency Cronbach Alpha of 0.93. In another study conducted by Alkariya (2017) and Prabowo (2017) it was found that HSCL-25 had internal consistency Cronbach Alpha of 0.928. Centrality Religiosity Scale-15 (Huber and Huber, 2012) is used to measure religiosity. In this study used CRS15 Indonesian version that has been translated, adjusted, and modified to be used in the Indonesian culture by Ratnasari (2017). Huber and Huber (2012) in his research assume that the general measurement of the five dimensions of CRS provides an overall estimate of one's personal religiosity and a person's religiosity score will increase as the overall dimension increases. 
Procedure. The preparation of this study began in January 2017. After all the preparation is completed, a pilot study was conducted to see if the CRS-15 can be understood clearly by the participants. 10 participants selected randomly to fill in the CRS-15. These participants are college student aged 18 to 25 . After they fill in the CRS-15, they have to answer several questions about the CRS-15 such as 'is there any words that hard to understand?', 'is there any term that used in this form which somehow not relevant to your religion? and 'do you have any suggestion about this form?'. After that several revisions were made in other to adjust the CRS-15. The adjustment that was added is the change from "Tuhan" to "Tuhan atau sesuatu yang Maha Hebat". For the HSCL-25, because it already used for the same population in the previous study conducted by Alkariya (2017) and Prabowo (2017), the pilot study for HSCL-25 was not conducted.

At the end of March, the data collection process began. There are two forms of questionnaires, online and offline. While the online were using Google form facility, the offline questionnaire took form in a mini booklet. For 14 days, both forms of questionnaires was distributed to the target participant. The offline questionnaires were distributing mostly after a lecturer left the class, and there no limit on how long they finish the questionnaire. The researchers also visit some other campuses and distribute the questioner directly to students that available and willing to fill in the questioner. Meanwhile, the online questionnaire was posted on various college group chat to ensure that only college student that has the online link. This group chat not only the one that available on Facebook but also in application Line. We make an advertisement picture where there are a visible link and a photo of the bag that we are going to give to the lucky respondents, this way we hope to get more respondents. This picture posted along with the message about this research in the college student groups in Facebook and Line. We make sure that the link only posted on college student related groups. We also ask several questions in the online form related to college life, to filter out respondents that not actually a college student. By doing so we filter around 50 data, some of them are repeated data or data that not match our criteria of respondents.

\section{Results}

The total research data obtained and used are 1,959. Table 1 provides an overview of research respondents based on demographic data consisting of gender, marital status, age, ethnicity, and religion. Referring to Table 1, the age of study respondents varies, from 18 to 25 years, this is corresponding to the age limit of emerging adult from Arnett (2000). Most of the respondents are aged 21 with the number 557 and 20 with the number 483. Meanwhile, the distribution of responder based on gender more female respondents with the number reached 1457 or $74.7 \%$.

Table 2 shows the result of the statistic analysist, it was found that there was a significant negative relationship between the belief dimension and psychological distress $(\mathrm{r}=-0.065, \mathrm{n}=1959, \mathrm{p}<0.05$, two tails) and there was a significant negative relationship between the dimensions of public religious practices and the distress Psychological $(r=$ $-0.063, \mathrm{n}=1959, \mathrm{p}<0.05$, two tails). Furthermore, there is significant positive relationship between intellectual dimension and psychological distress $(\mathrm{r}=0.056, \mathrm{n}=1959, \mathrm{p}>0.05$, two tails), as well as personal religious practice dimensions and psychological distress $(\mathrm{r}=0.074, \mathrm{n}=1059, \mathrm{P}>0.01$, two tails). Meanwhile, there was no significant relationship between experiential dimension and psychological distress $(\mathrm{r}=-0.021, \mathrm{n}=1959, \mathrm{p}>$ 0.05 , two tails)

The statistic analysis of the determinant coefficient $\left(r^{2}\right)$ on the religiosity dimension that correlated significantly with the psychological distress. In this statistic analysis, the value of $r^{2}$ in the intellectual dimension is $r^{2}=0.0031$, so it can be concluded that $0.31 \%$ of the variability of the psychological distress score can be explained by the intellectual dimension. The result of belief dimension is $r^{2}=0,042$ so it can be concluded that $0.42 \%$ variability of psychological distress score can be explained by belief dimension. Furthermore, on the general dimension of religious practice $r^{2}=0.0039$, it can be concluded that $0.39 \%$ of the variability in psychological distress scores can be explained by the dimensions of general religious practice. In that dimension, In the private practice dimension $r^{2}=0.0054$ so $0.54 \%$ of the variability of the psychological distress score can be explained by the personal religious practice dimension.

Table 1

Research Respondents Demography

\begin{tabular}{|c|c|c|}
\hline Demography & $\mathrm{F}$ & $\%$ \\
\hline \multicolumn{3}{|l|}{ Gender } \\
\hline - Male & 502 & $25,6 \%$ \\
\hline - Female & 1457 & $74.4 \%$ \\
\hline \multicolumn{3}{|l|}{ Marital Status } \\
\hline - Marriage & 17 & $0,9 \%$ \\
\hline - Not yet marriage & 1942 & $99,1 \%$ \\
\hline \multicolumn{3}{|l|}{ Age } \\
\hline - 18 & 182 & $9.3 \%$ \\
\hline
\end{tabular}


Table 1

Research Respondents Demography

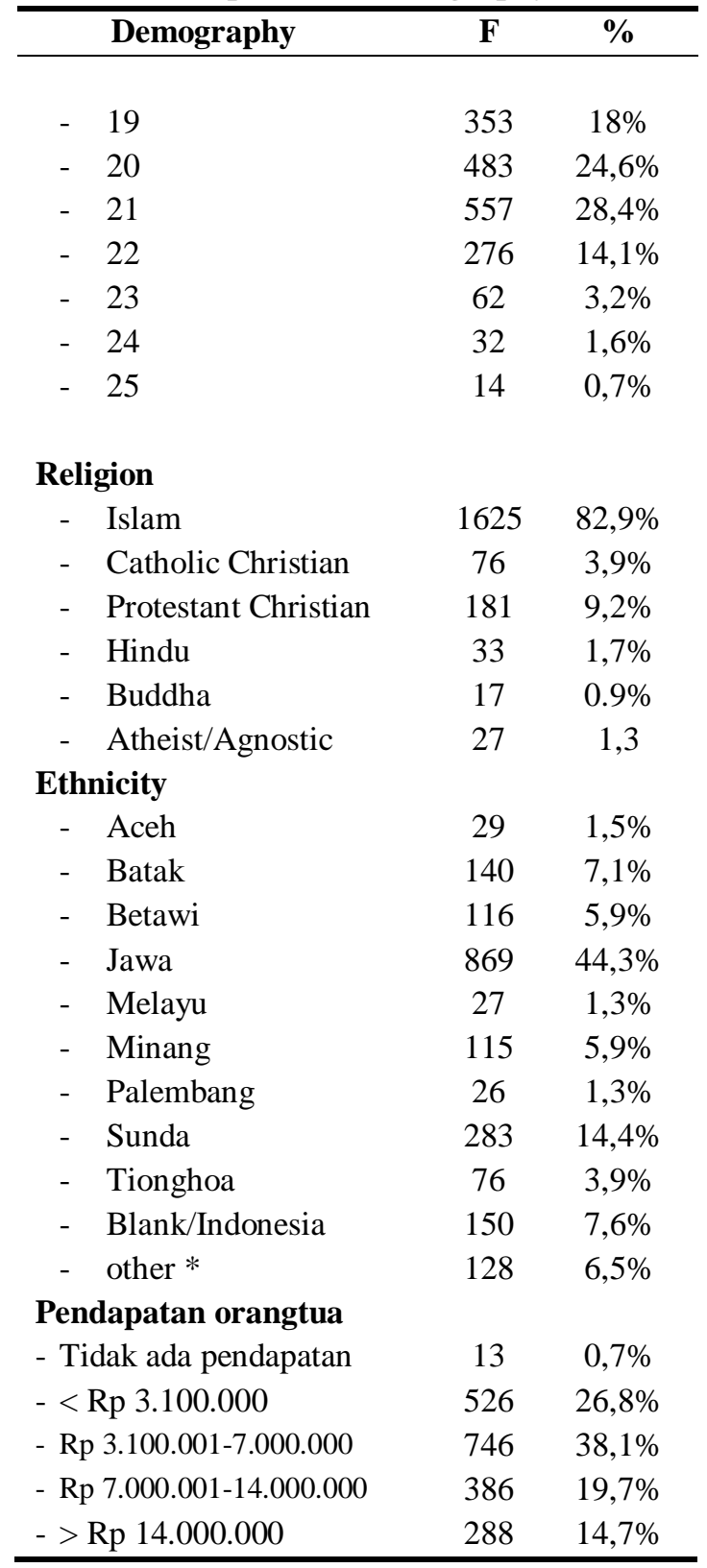

Table 2

Correlation between dimension of religiousity and psychological distress

\begin{tabular}{lccc}
\hline \multicolumn{1}{c}{\begin{tabular}{c} 
Dimension of \\
\multicolumn{1}{c}{ Religiosity }
\end{tabular}} & $\begin{array}{c}\text { Psychological } \\
\text { distress (r) }\end{array}$ & Sig. & $\mathrm{r}^{2}$ \\
\hline Intellectual & 0.056 & .014 & 0.0031 \\
Belief & -0.065 & .004 & 0.0042 \\
Public religious practice & -0.063 & .005 & 0.0039 \\
$\begin{array}{l}\text { Personal religious } \\
\text { practice }\end{array}$ & 0.074 & .001 & 0.0054 \\
Experience & -0.021 & .366 & 0.0004 \\
\hline
\end{tabular}

\section{Discussion \& Conclusion}

Discussion. This study aims to see whether there is a relationship between the dimensions of religiosity with psychological distress among students in Indonesia. The result shows that 4 out of 5 dimensions of religiosity have a significant relationship. The belief dimension and common religious practices dimension have a negative and significant relationship with psychological distress. That way can be interpreted that with increasing of trust to religion and also participate in a religious activity conducted together with a community can lower one's distress level. Stoppa and Lefkowitz (2010) found that in students despite the frequency of worship decreased, it did not decrease their belief in religion. In Indonesia alone, religious education starts from childhood and is included in the education curriculum. The exposure to religious education that begins early and continues until people grow older possibly strengthen the belief dimension in students who ultimately have a relationship with psychological distress. The dimensions of common religious practice also have the same relationship with the belief dimension. In short, it can be interpreted that by increasing participation in common activities that are done together with others can reduce students' psychological distress. This is also in line with findings from Frankel and Hewitt (1994) who found that students with Christian religious communities on campus, healthier, happier, and better dealing with distress. Frankel and Hewitt (1994) say it could happen because of the social support received from religious communities.

In this study, it was found that the belief dimension was higher than that of general religious practice. This is also in line with the findings of Stoppa and Lefkowitz (2010) which explains that decline on religious activity does not reduce the student belief in religion they are embraced. The student packed activity and the problems they face may prevent them from conducting religious activities with his community, but that does not diminish his belief in religion and the teachings he has received.

The next finding in this study is a positive and significant relationship between the intellectual dimension and personal religious practice with psychological distress in Indonesian students. In the intellectual dimension, knowledge of religious teachings is emphasized. With the existence of the relationship between the intellectual dimension and psychological distress, it means that with increasing knowledge of the teachings of religion it will also increase one's psychological distress. It may happen 
because of the guilt or sin that is felt after knowing the truth of the teachings. It is the same for dimensions of private religious practice, with increasing religious activity as well as increased psychological distress. The result contrast to previous findings by Rosmarin, Krumrei, and Andersson (2009) who found that religious practice can predict the decrease in one's distress. By looking at demographic data, the high level of psychological distress in the student may be due to his / her role as the student itself. As stated by Greenberg (2002) students face various things so that the level of distress experienced tend to be high. Not many new students, but older students also face various sources of stress, which in turn increase the psychological distress. Towbes and Cohen (in Greenberg, 2002) also revealed that students are particularly vulnerable to distress.

Limitation. In this study, we separate each of the dimension to see how each dimension correlates with psychological distress in college student's population. We do not count the religiosity dimension together to see religiosity as one big structure. For further research it could be done by count the religiosity as a whole, this could make the research a lot simpler. Secondly, in Indonesia right now there are 6 religions that are recognized by the

\section{References}

Acharya, S. (2009). Stress among students in developing countries: An overview. Psychology of Stress, 83-100.

Alkarisya, Anindita K. (2017). Hubungan antara distres psikologis dan keberfungsian keluarga pada mahasiswa. Skripsi. Fakultas Psikologi. Universitas Indonesia.

Arnett, J. J. (2000). Emerging adulthood: A theory of development from the late teens through the twenties. American Psychologist,55(5), 469-480. doi:10.1037//0003-066x.55.5.469

Arnett, J. J. (2006). Emerging adulthood: Understanding the new way of coming of age. Emerging adults in America: Coming of age in the 21 st century, 22, 3-19.

Astri, K. (2009). Hubungan antara stress dan religiusitas pada dewasa muda beragama islam (Undergraduate thesis). Universitas Indoensia.

Ellison, C. G., \& Fan, D. (2007). Daily spiritual experiences and psychological well-being among US adults. social indicators research, 88(2), 247271. doi:10.1007/s11205007-9187-2

Frankel, B. G., and Hewitt, W. E. (1994). Religion and WellBeing among Canadian University Students: The Role of Faith Groups on Campus. Journal for the Scientific Study of Religion,33(1), 62. doi:10.2307/1386637

Greenberg, J. S. (2002). Comprehensive stress management (7th ed.). Boston, MA: McGraw-Hill. government. In this study, we only use 5 of it. Next study could search more information and the teaching of it and include the $6^{\text {th }}$ religion in the research.

Conclusions Result from this research can be concluded that there is a significant negative relationship between the dimensions of belief and general religious practice with psychological distress on students in Indonesia. Furthermore, it is also found that there is a positive and significant relationship between the intellectual dimension and personal religious practice with psychological distress in Indonesian college students. Moreover, there is no significant relationship between the dimension of experience with psychological distress in students in Indonesia. The negative relationship between the belief dimension and general religious practice with psychological distress suggests that with the increase of one's belief in God and his religion and participating in religious activity in his religious community, the lower the level of psychological distress that the person feels. While a positive relationship between the intellectual dimension and personal religious practice with psychological distress shows that with increasing intellectual and personal religious practice the psychological distress also increases.

Huber, S., and Huber, O. W. (2012). The Centrality of Religiosity Scale (CRS). Religions, 3(4), 710-724. doi:10.3390/rel3030710

Jarvis, G. Eric, Kirmayer Laurance J., Weinfeld Morton, dan Lasry Jean-Claude. (2005). Religious practice and psychological distress: the importance of gender, ethnicity and immigrant status. Transcultural psychiatry, 42(4): 657-675. DOI: 10.1177/1363461505058921.s

Liu, E. Y., Schieman, S., dan Jang, S. J. (2011). Religiousness, Spirituality, and Psychological Distress in Taiwan. Review of Religious Research,53(2), 137-159. doi:10.1007/s13644-011-0011-8

Mirowsky, J., \& Ross, C. E. (2003). Social causes of psychological distress. Transaction Publishers.

O’Connor, D. B., Cobb, J., dan O’Connor, R. C. (2003). Religiosity, stress and psychological distress: no evidence for an association among undergraduate students. Personality and Individual Differences, 34(2), 211-217. doi:10.1016/s0191-8869(02)00035-1

Prabowo, Dio A. (2017). Hubungan antara distres psikologis dan resiliensi pada mahasiswa. Skripsi. Fakultas Psikologi. Universitas Indonesia.

Raza, H., Yousaf, A., dan Rasheed, R. (2016). Religiosity in relation with psychological distress and mental wellbeing among Muslims. International Journal of Research Studies in Psychology,5(2). doi:10.5861/ijrsp.2016.1371

Ratnasari Risa Dwi. (2017). The Effects of Self-compassion, Religiosity, and Income Support Group on the 
Subjective Well-being Parents of Mentally Retarded Children.Skripsi. Fakultas Psikologi UIN Jakarta.

Rosmarin, D. H., Krumrei, E. J., dan Andersson, G. (2009) Religion as a Predictor of Psychological Distress in Two Religious Communities. Cognitive Behaviour Therapy, 38(1), 54-64. doi:10.1080/16506070802477222

Ross, C. E. (1990). Religion and psychological distress. Journal for the Scientific Study of Religion, 236-245.

Stark, R., dan Glock, C. Y. (1968). American Piety: Patterns of religious commitment. Berkeley: University of California Press.
Stoppa, T. M., \& Lefkowitz, E. S. (2010). Longitudinal changes in religiosity among emerging adult college students. Journal of Research on Adolescence, 20(1), 23-38. doi:10.1111/j.1532-7795.2009.00630.x

Turnip, S. S., dan Hauff, E. (2007). Household roles, poverty and psychological distress in internally displaced persons affected by violent conflicts in Indonesia. Social Psychiatry and Psychiatric Epidemiology,42(12), 997-1004. doi:10.1007/s00127007-0255-3 